\title{
Oncolytic Newcastle Disease Virus Strain PV701
}

National Cancer Institute

\section{Source}

National Cancer Institute. Oncolytic Newcastle Disease Virus Strain PV701. NCI

Thesaurus. Code C2799.

An attenuated, replication-competent, oncolytic strain of Newcastle disease virus. PV701 selectively lyses tumor cells. The selectivity of this agent is related to defects in the interferon-mediated antiviral response found in tumor cells. ( $\mathrm{NCI04)}$ 